\title{
RANCANG BANGUN SISTEM ELECTROSPINNING UNTUK MENSINTESIS NANOFIBER POLIVINIL ALKOHOL DAN KARAKTERISASINYA
}

\author{
Aa Santosa, Eri Widianto, Ferry Restianto*) \\ Program Teknik Mesin \\ Fakultas Teknik - Universitas Singaperbangsa Karawang
}

\begin{abstract}
Abstrak: : Telah dilakukan penelitian tentang rancang bangun sistem electrospinning untuk mensintesis nanofiber polivinil alkohol (PVA) dan karakterisasinya. Tujuan dari penelitian ini adalah membuat electrospinning dengan memodifikasi syringe pump yang dapat bergerak kanan-kiri. Mesin electrospinning dibuat dari komponen-komponen yang mudah diperoleh. Pengujian electrospinning dilakukan dengan mensintesis nanofiber dari polimer PVA. Karakterisasi nanofiber PVA menggunakan Scanning Electron Microscope (SEM), hasil karakterisasi menggunakan SEM menunjukan ukuran diameter rata-rata nanofiber sebesar $(151,26 \pm 27,47078) \mathrm{nm}$ dan $(152,89 \pm 17,0341) \mathrm{nm}$ masing-masing untuk jarak needle ke collector $15 \mathrm{~cm}$ dan $12 \mathrm{~cm}$. Hasil menunjukan bahwa mesin electrospinning yang dibuat dapat menghasilkan serat (fiber) dengan ukuran nanometer.
\end{abstract}

Kata kunci: electrospinning, nanofiber PVA, SEM

\section{PENDAHULUAN ${ }^{1}$}

Perkembangan nanoteknologi yang pesat dalam beberapa tahun terakhir sangat berdampak pada perkembangan berbagai industri. Nanoteknologi merupakan pembuatan dan penggunaan material pada skala 1-100 $\mathrm{nm}$, dimana material disusun dalam orde atom-per-atom. Salah satu nanoteknologi yang sedang banyak dikembangkan adalah pembuatan serat nano (nanofiber). Nanofiber didefinisikan sebagai serat yang memiliki diameter 100-500 nm (Subbiah [1]). Nanofiber memilik sifat yang sangat khas, yaitu sangat kuat, rasio permukaan terhadap volume yang besar dan berpori. Sifat-sifat tersebut menjadikan nanofiber menjadi material yang sangat menjanjikan untuk dimanfaatkan pada berbagai bidang industri, seperti industri tekstil, komposit, otomotif, kertas, elektronik, optik, pertanian, kosmetik, kesehatan, kedokteran, olah raga dan farmasi ([Mohan [2], Dotti [3], Qian [4], Piras [5], Jia [6], Hui wu [7], Hui Wu [8], Syed [9], Lijun Yang [10]). Pembuatan nanofiber dapat dilakukan dengan cara drawing, template synthesis dan electrospinning. Dari ketiga metode pembuatan serat tersebut, electrospinning

1") ferryrestianto@gmail.com merupakan teknik yang cukup sederhana namun mampu menghasilkan serat nano dengan rentang ukuran paling kecil yakni 0,04-2 mikron (Wahyudi [11]).

Proses electrospinning menggunakan larutan polimer yang disiapkan pada tabung semprot (syringe) kemudian dilewatkan melalui sebuah lubang spinnered (jet) dengan ujung kecil dan ditarik dengan medan listrik tegangan tinggi arus searah. Larutan yang ditarik oleh medan listrik berbentuk droplet/jet karena pengaruh tegangan permukaan. Jet tersebut bergerak menuju kolektor dan pada bagian ini serat nano akan terkumpul. Keunggulan dari electrospinning yaitu proses mudah, mampu mengendalikan morfologi, keseragaman, porositas dan menghasilkan nanofiber yang cukup panjang (kontinu), namun tingkat produksinya masih rendah. Keunggulan teknologi ini memungkinkan untuk dikembangkan lebih lanjut sebagai mesin pembuat serat mikronano dalam skala besar (He [12]).

Teknologi ini relatif baru yang dapat diamati dari publikasi ilmiah internasional yang terus meningkat dari tahun 2000 kurang dari 100, 
Infomatek Volume 19 Nomor 2 Desember 2017 : 101 - 108 hingga tahun 2007 menjadi lebih dari 500 publikasi dengan prosentase terbesar yang masih dikuasai oleh negara-negara maju seperti Amerika Serikat, Korea dan China (Pikett [13]). Hal ini membuka peluang bangsa Indonesia untuk berkompetisi di tingkat Internasional. Penguasaan teknologi nano khususnya electrospinning akan menempatkan Indonesia sejajar dengan negaranegara maju dalam mengembangkan nanofiber dan aplikasinya sesuai dengan kebutuhan bangsa.

Perancangan mesin electrospinning meliputi konsep perancangan, perencanaan wujud yang dibantu pembuatannya di workshop pemesinan, kemudian perakitan bagian elemen-elemen mesin yang telah dibuat.

Berdasarkan uraian di atas, maka dalam penelitian ini akan dirancang dan dibuat mesin electrospinning dengan desain syringe pump yang dapat bergerak kanan-kiri (right-left). Desain dan pengembangan mesin electrospinning dilakukan dengan menggunakan bahan baku dan komponen lokal yang mudah didapat di wilayah Kabupaten Karawang dan dibantu dengan Software Autodesk Inventor 2015. Pengujian mesin electrospinning dilakukan untuk pembuatan nanofiber Polivinil Alkohol (PVA). Karakterisasi nanofiber menggunakan Scanning Electron Microscopy (SEM) untuk mengetahui morfologi dan ukuran diameter nanofiber. Mesin electrospinning yang dihasilkan diharapkan dapat menghasilkan serat (fiber) dengan ukuran diameter dalam skala nanometer.

Pada penelitian yang dilakukan, permasalahan dititikberatkan pada rancang bangun mesin eletrospinning namun aplikasi nanofiber dan parameter-parameter belum dikaji dalam penelitian ini.

Tujuan pembahasan pada penelitian ini adalah:

a. Merancang dan membuat mesin electrospinning untuk memproduksi serat nano (nanofiber) dengan memodifikasi syringe pump.

b. Mensintesis nanofiber berbasis polimer PVA (Polivinil Alkohol) menggunakan electrospinning yang telah dibuat.

\section{METODOLOGI}

Langkah-langkah penelitian yang dilakukan adalah seperti yang dijelaskan pada Gambar 1 berikut ini.

\section{Gambar 1}

Flowchart pembuatan dan pengujian electrospinning

\section{Tahap Persiapan}

Tahap persiapan meliputi kajian pustaka mengenai proses pembuatan mesin electrospinning dan aplikasinnya dalam mensintesis nanofiber. Alat dan bahan dipersiapkan seperti : kaca akrilik, motor listrik dc, trafo flyback dan rangkaian step up, kabel listrik, jarum suntik, gunting, penggaris dan pinset, aluminiumfoil, preparat, beaker glass, magnetic hot plate stirrer, timbangan digital, chamber mesin, Polivinil Alcohol (PVA) dan aquades

2. Tahap Perancangan dan Perakitan Tahapan perancangan dan perakitan berupa perancangan syringe pump dan High voltage.

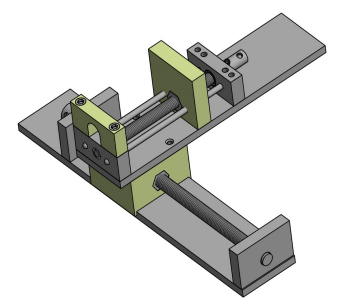

Gambar 2 
Keseluruhan syringe pump

3. Tahapan Pembuatan Program

Program yang digunakan untuk High Voltage menggunakan Program Sketch Arduino. Program pertama yang dibuat merupakan program untuk tampilan kalimat dan nilai tegangan di $\angle C D$.

4. Tahap Pengujian

Mesin electrospinning yang telah selesai dibuat selanjutnya dilakukan pengujian untuk memproduksi nanofiber. Nanofiber dibuat menggunakan bahan yang banyak dipakai dan diteliti yaitu PVA. Pada penelitian ini digunakan larutan PVA $10 \%$. Serbuk PVA 1.111 gram dilarutkan ke dalam $10 \mathrm{ml}$ aquades yang sebelumnya telah dipanaskan pada suhu $90{ }^{\circ} \mathrm{C}$, kemudian diaduk menggunakan magnetic hot plate stirrer hingga homogen. Selanjutnya larutan dimasukkan ke dalam suntikan, dan siap dilakukan proses electrospinning. Nanofiber yang diperoleh selanjutnya dikarakterisasi menggunakan mikroskop optik dan SEM untuk mengetahui ukuran diameter fiber tersebut. Pembuatan larutan PVA sebelum melakukan pengujian electrospinning:

PVA $10 \%$

Dengan persamaan 4.1

Keterangan : adalah berat PVA per gram. Maka didapat perhitungan :

$10=10+$

gram

dalam $10 \mathrm{ml}$ aquades. Jadi untuk mendapatkan PVA $10 \%$ dengan
Rancang Bangun Sistem Electrospinning untuk Mensintesis Nanofiber Polivinil Alkohol dan Karakterisasinya melarutkan 1,111 gram serbuk PVA ke dalam $10 \mathrm{ml}$ aquades.

\section{ANALISIS DAN PEMBAHASAN}

Telah dilaksanakan penelitian tentang Electrospinning. Komponen utama electrospinning High Voltage, Syringe Pump dan collector yang telah dibuat ditunjukkan pada Gambar 3.

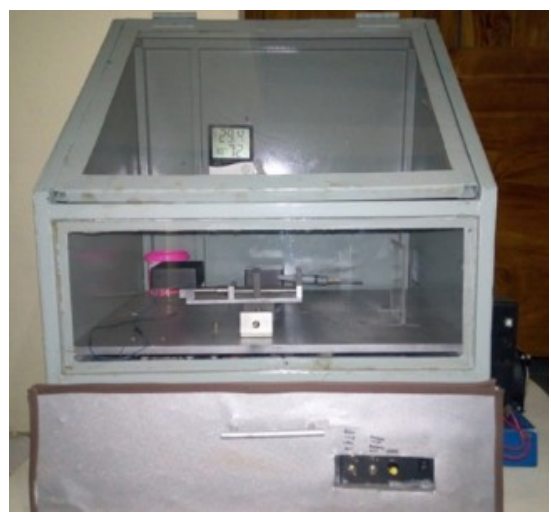

Gambar 3

Electrospinning yang telah dibuat

Tabel 1

Spesifikasi hasil pembuatan syringe pump

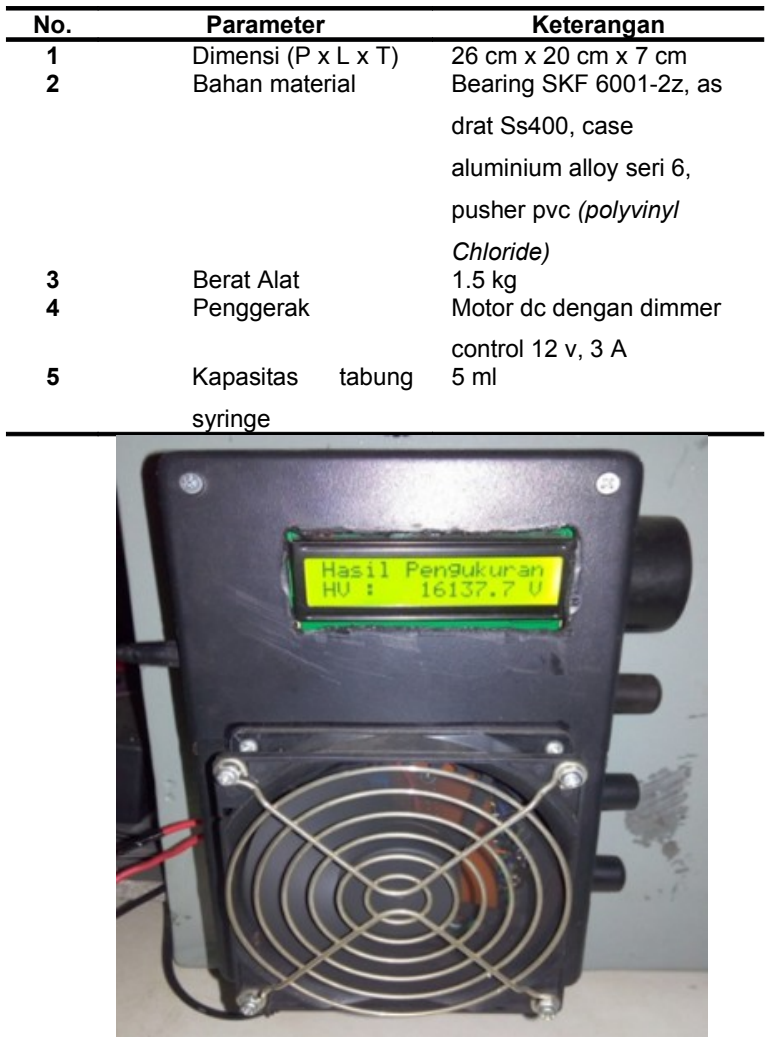


Infomatek Volume 19 Nomor 2 Desember 2017 : 101 - 108

Gambar 4

Nilai tegangan yang keluar pada tampilan $L C D$

Tabel 2

Rentang tegangan yang keluar dengan waktu \pm 20 menit

\begin{tabular}{cc}
\hline Waktu (menit) & $\begin{array}{c}\text { Nilai tegangan yang keluar } \\
\text { padaLCD 16x2 (v) }\end{array}$ \\
\hline \pm 20 menit & $16137-16300$ \\
\hline
\end{tabular}

Setelah mesin electrospinning dibuat maka dilakukan pengujian untuk mendapatkan serat berukuran nanometer.

Tabel 3

\begin{tabular}{|c|c|c|c|c|c|}
\hline \multicolumn{6}{|c|}{ Parameter Pengujian Electrospinning } \\
\hline $\begin{array}{l}\text { Nama } \\
\text { Sampel }\end{array}$ & $\begin{array}{l}\text { Jarak tip- } \\
\text { collector } \\
\text { (cm) }\end{array}$ & $\begin{array}{c}\mathrm{D} \\
\text { dalam } \\
\text { needle } \\
(\mathrm{mm})\end{array}$ & $\begin{array}{l}\text { Larutan } \\
\text { PVA (\%) }\end{array}$ & $\begin{array}{c}\text { Tegangan } \\
\text { (Volt) }\end{array}$ & $\begin{array}{l}\text { Waktu } \\
\text { (menit) }\end{array}$ \\
\hline NF-01 & 15 & 0,4 & 10 & $\begin{array}{c}16137- \\
16300\end{array}$ & 10 \\
\hline NF-02 & 12 & $\overline{0,4}$ & 10 & $\begin{array}{l}16137- \\
16300\end{array}$ & 10 \\
\hline
\end{tabular}

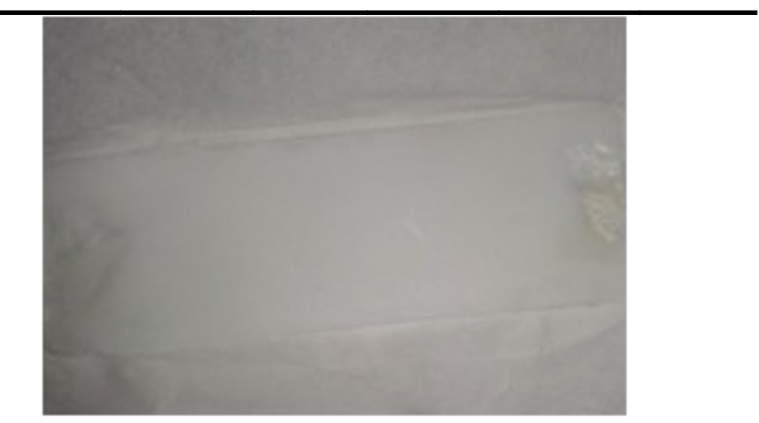

Gambar 5

Sampel Hasil Electrospinning

Struktur morfolgi nanofiber PVA sampel NF-01 ditunjukkan pada gambar 6 berikut :

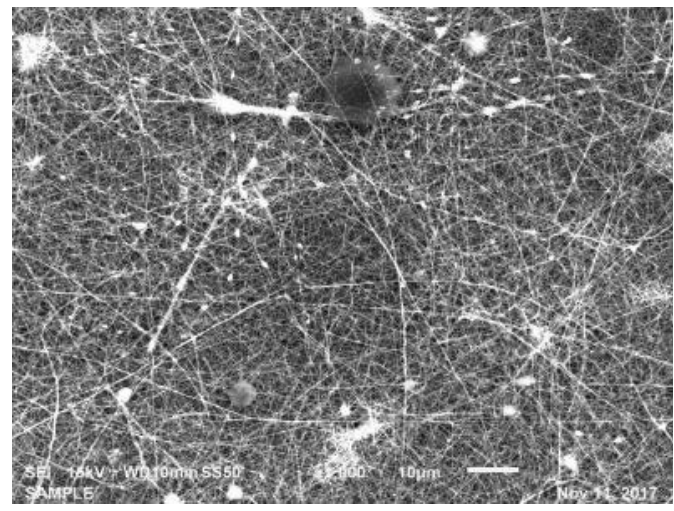

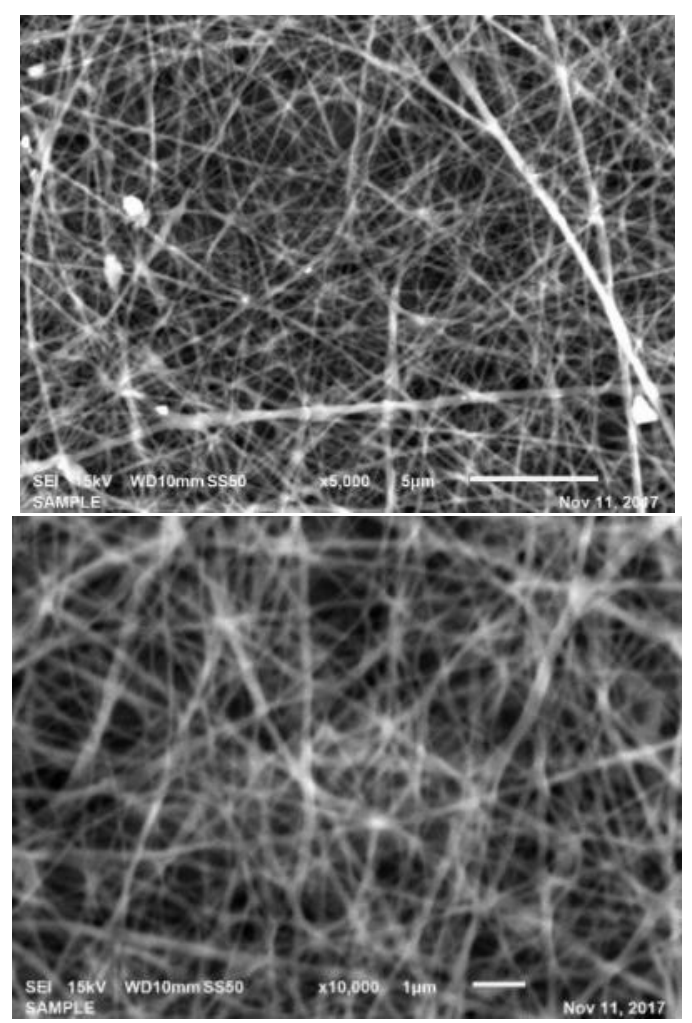

(d)

Gambar 6

Struktur morfologi nanofiber NF-01 menggunakan SEM dengan perbesaran (a) 1000x, (b) 5000x, (c) 10.000x; (d)

Distribusi ukuran nanofiber

Morfologi nanofiber NF-01 menunjukan tidak begitu banyak gumpalan PVA yang tidak berhasil ditarik oleh medan listrik. Terdapat 2 (dua) lubang pada gambar (a), karena pada saat melakukan pengujian diduga udara lingkungan mempengaruhi proses electrospinning, sehingga larutan PVA menuju collector kemungkinan menguap seblum menjadi serat.

Ukuran rata-rata diameter nanofiber NF-01 terlihat pada Gambar 6(d) yaitu $(151,26 \pm 27,47078) \mathrm{nm}$. Hasil pengujian menunjukan bahwa electrospinning yang dibuat dapat menghasilkan nanofiber dengan ukuran skala nanometer.

Struktur morfologi nanofiber PVA sampel NF-02 ditunjukkan pada Gambar 7 berikut. 

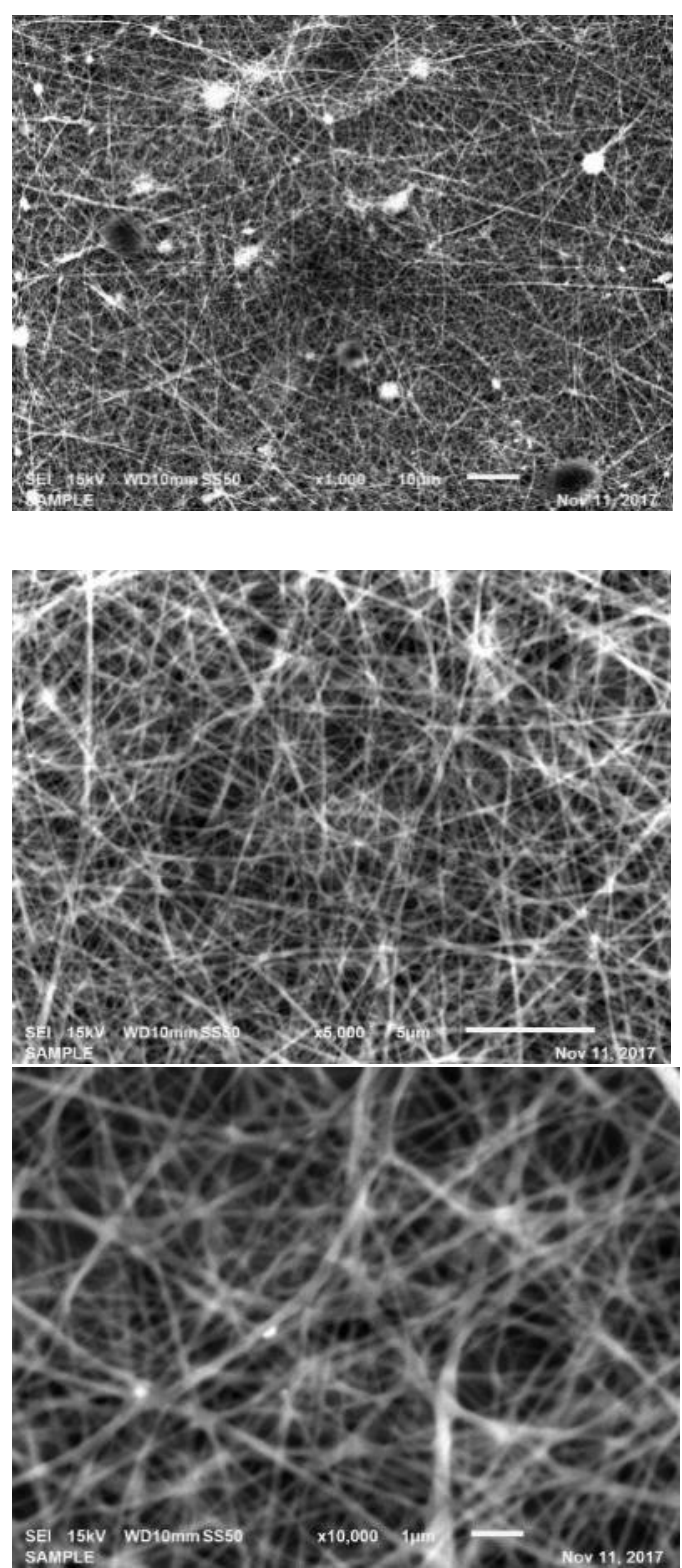

(d)

Gambar 7

Struktur morfologi nanofiber NF-02 menggunakan SEM dengan perbesaran (a) 1000x, (b) 5000x, (c) 10.000x; (d)

Distribusi ukuran nanofiber

Morfologi nanofiber NF-02 secara keseluruhan belum homogen. Serat yang terbentuk terlihat belum kontinyu, disamping itu diantara serat terdapat gumpalan PVA yang tidak berhasil ditarik oleh tegangan tinggi medan listrik. Penyebab gumpalan juga diduga karena tidak seimbangnya laju alir larutan PVA, diperkirakan terlalu cepat keluar dari lubang spinneret sehingga jatuh
Rancang Bangun Sistem Electrospinning untuk Mensintesis Nanofiber Polivinil Alkohol dan Karakterisasinya menetes berbentuk gumpalan. Selain itu jarak spinneret dengan collector juga berpengaruh terhadap larutan, semakin dekat jarak menyebabkan larutan PVA yang ditarik oleh medan listrik ke collector belum terbentuk serat. Gambar (a), (b) dan (c) merupakan pembesaran 1000x, 5000x dan 10.000x nanometer.

Ukuran rata-rata diameter nanofiber NF-02 terlihat pada Gambar $7(\mathrm{~d})$ yaitu $(152,89 \pm 17,0341) \mathrm{nm}$. Hasil pengujian menunjukan bahwa electrospinning yang dibuat dapat menghasilkan nanofiber dengan ukuran skala nanometer.

\section{KESIMPULAN}

Dari hasil penelitian yang telah dilakukan, dapat disimpulkan beberapa hal sebagai berikut :

1. Mesin Electrospinning berhasil dibuat dengan bahan dan alat lokal yang mudah diperoleh.

2. Nanofiber PVA berhasil disintesis menggunakan electrospinning dengan ukuran diameter rata-rata $150 \mathrm{~nm}$.

\section{DAFTAR PUSTAKA}

[1] Subbiah T. et.al, 2005. Electrospinning of Nanofiber, Journal of Applied Polymer Science, 2005, 96, 557-569.

[2] Mohan A. 2002, Formation and Characterization of Electrospun Nonwoven web, Textile Management and Technology, North Carolina State University.

[3] Dotti F. et al, 2007, Electrospun Porous Mats for High Efficiency Filtration, Journal of Industrial Textile, 37, 151-162.

[4] Qian L. et.al, 2004. Application of Nanotechnology for High Performance Textiles, Journal of Textile and Apparel Technology and Management, 4,1, 1-7. 
Infomatek Volume 19 Nomor 2 Desember 2017 : 101 - 108

[5] Piras et al, 2008. New Multicomponent Bioerodible Electrospun Nanofibers for Dualcontrolled Drug Realease, Journal of Bioactive and compatible Polymers, 23, 423, 423-443.

[6] Jia-Horng Lin, Chao-Tsang Lu, Jin-Jia Hu, Yueh-Sheng Chen, Chen-Hung Huang, and Ching-Wen Lou, 2012, Property Evaluation of Bletilla striata/Polyvinyl Alcohol Nano Fibers and Composite Dressing, Journ. of Nanomat., Vol. 2012, pp 1-7.

[7] Hui Wu, Dandan Lin, Rui Zhang, and Wei Pan, 2008. ZnO Nanofiber Field-Effect Transistor Assembled by Electrospinning, J. Am. Ceram. Soc., 91 [2] pp 656-659.

[8] Hui Wu, Liangbing $\mathrm{Hu}$, Michael W. Rowell, Desheng Kong, Judy J. Cha, James R. McDonough, Jia Zhu, Yuan Yang, Michael D. McGehee, 2010, Electrospun Metal Nanofiber Webs as High-Performance Transparent Electrode, NanoLetter, 10, 4242-4248.

[9] Syed Abdul Moiz1, Ahmed Muhammad Nahhas1, HanDon Um,Sang-Won Jee,
Hyung Koun Cho4, Sang-Woo Kim and Jung-Ho Lee. 2012. A stamped PEDOT:PSS-silicon nanowire hybrid solar cell, Nanotechnology, 23, 145401-145408.

[10] Lijun Yang, Wallace Woon-Fong Leung, 2011. Improvement of Dye Sensitized Solar Cells With Nanofiber-Based Anode, ASME 2011 International Mechanical Engineering Congress and Exposition (IMECE2011) , November 11- 17, 2011 , Denver, Colorado, USA.

[11] Wahyudi T. et.al, 2011. Pembuatan Serat Nano menggunakan Metode Electrospinning, 2011, Arena tekstil Vol 26 No.1-Juni 2011 :160.

[12] He, J. H., Y. Liu, L. F. Mo, Y. Q. Wan, dan L. Xu. 2008. Electrospun Nanofibers and Their Applications. Shawbury, shrewsbury, Sropshire, SY4-4NR, UK: iSmithers e-Book.

[13] Pickett, A.N., 2012. Electrospinning Applications in Mechanochemistry and Multifunctional Hydrogel Materials 